\title{
HUBUNGAN PENYULUHAN DAN PENDAPATAN USAHATANI UBI JALAR (Ipomea batatas) DI KELOMPOK TANI HURIP
}

\author{
S. Masithoh ${ }^{1 \mathrm{a}}$, I. Novita ${ }^{1}$, DA. Widara ${ }^{1}$ \\ ${ }^{1}$ Jurusan Agribisnis, Fakultas Pertanian Universitas Djuanda Bogor \\ Jalan Tol Ciawi No. 1 Kotak Pos 35 Bogor 16720 \\ ${ }^{a}$ Korespondensi: Siti Masithoh. Telp: 0817404974; E-mail: sitmasitoh@unida.ac.id
}

\begin{abstract}
This research was aimed to analyze the relation of farmers income and extention aspects. A descriptive and qualitative analysis was used. Farming business income was analyzed by using a multiple linear regression method done by using an SPSS 16 application software. Selection of sample farmers using simple random sampling (select simple random sampling), selected 30 farmers example of 105 farmers. Based on the calculation through SPSS 16, the result of multiple linear regression analysis estimation, the relation of respondent characteristic shows the determination value (R2) equal to 78.9 percent with the correlation determination value (R square) 77, 0 percent at $\alpha 0,2$ and 0,05 and the results of multiple linear regression analysis estimation on the aspect of counseling, showed the value of coefficient of determination (R2) of 68.7 percent with the value of determination terkolerasi (R square) of 76.6 percent at $\alpha 0.2$ and 0.05 . Factors that have significant effect on farm income in farmer group of Hurip are age, education level, farming experience, frequency of extension visit, material suitability, information service and participation of counseling while the factors that do not have real effect are member status.
\end{abstract}

Key words: extension. farmer income, multiple regression analysis

\begin{abstract}
ABSTRAK
Penelitian ini bertujuan untuk menganalisis hubungan antara penyuluhan dengan pendapatan petani ubi jalar. Pemilihan petani contoh menggunakan simple random sampling (pengambilan sampel acak sederhana) sebanyak 30 orang petani contoh dari populasi 105 orang petani. Digunakan analisis analisis Regresi Linear Berganda. Berdasarkan perhitungan melalui SPSS 16, hasil pendugaan analisis regresi linear berganda, hubungan karakteristik responden menunjukan nilai determinasi $\left(\mathrm{R}^{2}\right)$ sebesar 78,9 persen dengan nilai determinasi terkolerasi ( $\mathrm{R}^{\text {square}}$ ) sebesar 77, 0 persen pada $\alpha 0,2$ dan 0,05 serta hasil pendugaan pada aspek penyuluhan, menunjukan nilai koefisien determinasi $\left(\mathrm{R}^{2}\right)$ sebesar 68,7 persen dengan nilai determinasi terkolerasi $\left(\mathrm{R}^{\text {square }}\right.$ ) sebesar 76,6 persen pada $\alpha 0,2$ dan 0,05 . Faktor-faktor yang berpengaruh nyata terhadap pendapatan usahatani di kelompok tani Hurip adalah umur, tingkat pendidikan, pengalaman usahatani, frekuensi kunjungan penyuluh, kesesuaian materi, pelayanan informasi dan partisipasi penyuluhan sedangkan faktor-faktor yang tidak berpengaruh nyata adalah, status anggota.
\end{abstract}

Kata kunci : penyuluhan, pendapatan petani, regresi linier berganda 


\section{PENDAHULUAN}

Secara umum peningkatan pendapatan petani sangatlah ditentukan oleh petani itu sendiri sebagai pelaku utama pembangunan pertanian. Tetapi kenyataannya tidak terlepas dari bimbingan dan bantuan pemerintah serta salah satunya adalah melalui kegiatan penyuluhan, dimana secara langsung petani dibimbing dan diberi bantuan oleh pelaku penyuluh pertanian agar petani memiliki keterampilan yang lebih, dengan harapan dapat lebih meningkatkan pendapatan petani.

Jawa Barat menjadi salah satu propinsi yang memiliki tingkat produksi ubi jalar cukup tinggi, pada tahun 2007 produksi ubi jalar mencapai 375,7 ton dengan luas panen 28, 1 ha kemudian meningkat pada tahun 2008 menjadi 376,5 ton dengan luas panen 27,3 ha, dan ditahun 2009 menjadi 469,6 ton dengan luas panen 33,4 ha (BPS, 2010). Meski dengan produksi yang terus meningkat hal ini tidak berbanding lurus dengan pendapatan petani ubi jalar tersebut sehingga kesejahteraan kehidupan petani masih harus ditingkatkan. Ubi jalar merupakan salah satu tanaman palawija yang memiliki potensi besar dalam perkembangan sektor pertanian di Jawa Barat, dan Kabupaten Bogor merupakan salah satu kabupaten di Jawa Barat dengan tingkat produksi ubi jalar memiliki trend yang terus meningkat setiap tahun, khususnya Desa Cikarawang yang berada di Kecamatan Dramaga, Kabupaten Bogor. Tingkat produksi ubi jalar mencapai 30 ton per hektar. Dengan produksi yang cukup tinggi itu sayangnya kehidupan petani masih dalam kategori berpendapatan rendah.

\section{BAHAN DAN METODE}

\section{Penyuluhan Pertanian}

$$
\text { Menurut Mardikanto }
$$

Penyuluha pertanian adalah suatu sistem pendidikan bagi masyarakat (petani) untuk membuat mereka tahu, mau dan mampu berswadaya melaksanakan upaya peningkatan produksi pendapatan atu keuntungan dan perbaikan kesejahteraan keluarga/ masyarakatnya. Dalam melaksanakan kegiatan penyuluhan agar dapat berlangsung efektif dan efisien, maka terlebih dahulu harus dipahami falsafah penyuluhan. Falsafah penyuluhan menurut Suhardiyono (1990) yang merupakan dasar dalam bekerja dilandasi oleh tiga hal: (1) penyuluhan merupakan suatu proses pendidikan, (2) penyuluhan merupakan proses demokrasi dan (3) penyuluhan merupakan proses yang terus menerus. Artinya, penyuluhan merupakan proses pendidikan yang membawa perubahan yang diharapkan oleh seseorang ataupun masyarakat tani tersebut dan dilakukan secara terus menerus.

\section{Konsep Pendapatan Usahatani}

Mubyarto (1989), mengemukakan bahwa usahatani merupakan himpunan dari sumber-sumber alam yang terdapat di tempat itu yang diperlukan untuk produksi pertanian. Tujuan setiap petani dalam melaksanakan usahataninya berbeda-beda. Apabila dorongannya untuk memenuhi kebutuhan keluraga baik melalui atau tanpa peredaran uang, maka usahatani tersebut disebut usahatani pencukup kebutuhan keluarga (Subsistence Farm). Sedangkan bila motivasi yang mendorongnya untuk mencari keuntungan, maka usahatani yang demikian disebut usahatani komersial (Commercial Farm). Faktor-faktor yang mempengaruhi produksi dalam usahatani terdiri dari faktor internal dan eksternal. Faktor internal antara lain penggunaan input, teknik bercocok tanam dan teknologi. Sedangkan faktor eksternal seperti cuaca, iklim, hama dan penyakit, penemuan teknologi baru, fasilitas irigasi, tingkat harga output dan input, ketersediaan lembaga perkreditan, adat istiadat masyarakat dan kebijaksanaan pemerintah.

Soeharjo (1998) menjelaskan penerimaan usahatani berwujud tiga hal, yaitu hasil penjualan tanaman, ternak, ikan, atau produk yang akan dijual, produk yang dikonsumsi pengusaha dan 
keluarganya selama melakukan kegiatan, dan kenaikan nilai inventaris. Istilah lainnya dalam penerimaan usahatani adalah pendapatan kotor usahatani. Pendapatan kotor usahatani merupakan nilai produk total usahatani dalam jangka waktu tertentu, baik yang dijual maupun tidak dijual, mencakup semua produk yang dijual, dikonsumsi rumah tangga petani, digunakan dalam usahatani untuk bibit ataupun makanan ternak, digunakan untuk pembayaran dan disimpan atau ada di gudang pada akhir tahun (Soekartawi et all. 1986).

\section{Lokasi Penelitian}

Penelitian dilakukan di Kelompok tani Hurip yang merupakan petani Ubi Jalar di Desa Cikarawang, Kabupaten Bogor. Pemilihan petani contoh menggunakan simple random sampling (pengambilan sampel acak sederhana) dari populasi petani yang ada. Dari populasi sebanyak 105 orang petani, terpilih 30 orang petani contoh. Penelitian dilakukan pada bulan Februari hingga Maret 2014. Analisis yang digunakan dalam penelitian ini adalah Analisis Regresi Linear Berganda. Metode yang digunakan adalah analisis regresi linear berganda. Sugiyono (2010) menjelaskan bahwa regresi linear berganda merupakan alat analisis yang digunakan untuk meramalkan atau mengetahui pengaruh dari dua atau lebih variabel independen sebagai faktor prediktor terhadap variabel dependen.

Rumus :

$$
\begin{aligned}
& Y=a+b_{1} X_{1}+b_{2} X_{2}+b_{3} X_{3}+b_{4} X_{4}+b_{5} X_{5}+b_{6} X_{6}+ \\
& b_{7} X_{7}+b_{8} X_{8}
\end{aligned}
$$

Keterangan:

$\mathrm{Y}=$ Pendapatan $(\mathrm{Rp})$

$\mathrm{a}=$ konstanta

$\mathrm{b}=$ koefisien regresi

$\mathrm{x}_{1}=\operatorname{Umur}$ (Tahun)

$\mathrm{x}_{2}=$ Tingkat Pendidikan (Tahun)

$\mathrm{x}_{3}=$ Pengalaman bertani (Tahun)

$\mathrm{x}_{4}=$ Status anggota kelompok tani (dummy variable) $; \mathrm{D}=0$ Petani bukan peserta program PUAP, D $=1$ Petani peserta program PUAP

$\mathrm{x}_{5}=$ Kesesuaian materi penyuluhan (skor)

$\mathrm{x}_{6}=$ Pelayanan informasi penyuluhan(skor)

$\mathrm{x}_{7}=$ Partisipasi kegiatan penyuluhan (skor)

$\mathrm{x}_{8}=$ Kunjungan penyuluh (frekuensi)

\section{HASIL DAN PEMBAHASAN}

\section{Gambaran Umum Lokasi Penelitian}

Desa Cikarawang adalah salah satu desa yang terletak di Kecamatan Dramaga. Luas wilayah desa ini sebesar 226,56 Ha. Dilihat dari topografi dan kontur tanah Desa Cikarawang secara umum berupa dataran dan persawahan dengan ketinggian $193 \mathrm{~m}$ di atas permukaan laut. Kondisi suhu rata-rata harian $25^{\circ}-30^{\circ}$ C. Desa Cikarawang terdiri dari tiga dusun, $7 \mathrm{RW}$, dan 32 RT. Wilayah Desa Cikarawang terbagi atas tiga Dusun dan tujuh Rukun Warga (RW). Wilayah ini terbagi lagi ke dalam wilayah kelompok masyarakat, yaitu 32 Rukun Tetangga (RT) yang menyebar di 11 kampung. Luas wilayah Desa Cikarawang menurut penggunaannya dapat dilihat pada Tabel 1.

Tabel 1. Luas Wilayah Menurut Penggunaan Lahan Di Desa Cikarawang Tahun 2009

\begin{tabular}{lrr}
\hline \multicolumn{1}{c}{ Wilayah } & Luas(ha) & Persentase(\%) \\
\hline Pemukiman & $37.854,00$ & 15,10 \\
Persawahan & $194.572,00$ & 77,63 \\
Perkebunan & $18.226,00$ & 7,27 \\
Kuburan & 0,60 & 0,00024 \\
Pekarangan & 1,21 & 0,00048 \\
Perkantoran & 0,01 & 0,000006 \\
\hline Total Luas & $250.653,82$ & 100,00 \\
\hline
\end{tabular}

Sumber : Buku Monografi Desa Cikarawang, 2009 (Diolah) 
Jumlah Penduduk Desa Cikarawang adalah sebanyak 8.227 orang dengan jumlah penduduk perempuan sebanyak 4.028 orang dan laki-laki sebanyak 4.199 orang. Jumlah penduduk paling banyak adalah pada sebaran umur antara 16-56 tahun yaitu sebanyak 6.087 orang (73,98 persen). Jumlah penduduk di Desa Cikarawang mayoritas bermata pencaharian sebagai buruh swasta sebesar 42,64 persen dan sebesar 17,62 persen berprofesi di sektor pertanian. Hal ini menunjukan bahwa luas persawahan yang besar di desa tersebut belum dimanfaatkan dengan optimal oleh masyarakat setempat atau hanya dijadikan sebagai pekerjaan sampingan. Selain menggantungkan hidupnya sebagai buruh swasta, penduduk di Desa Cikarawang juga menggantungkan hidup pada sektor pertanian.

\section{Kelompok Tani Hurip}

Kelompok Tani Hurip adalah kelompok tani tertua di Desa Cikarawang yang pendirinya di latar belakangi oleh keinginan dari para petani untuk bekerjasama dalam memajukan pertanian desa. Kelompok tani ini berdiri sejak tahun 1974 yang diketuai oleh Bapak Kuming dan selanjutnya dari tahun 2000 sampai sekarang kelompok tani Hurip diketuai oleh Ahmad Bastari, yang merupakan cucu menantu dari ketua sebelumnya. Sekretariat kelompok tani Hurip (KTH) beralamat di Kampung Carangpulang, Bubulak RT 04, RW 03, No 43, Dusun II, Desa Cikarawang, Kecamatan Dramaga, Kabupaten Bogor, Provinsi Jawa Barat. Anggota kelompok tani Hurip adalah para petani yang tinggal di Kampung Bubulak dan sebagian besar diantara mereka memiliki hubungan keluarga.

Pada periode kepemimpinan pertama (1974-2000) belum terbentuk kepengurusan kelompok tani Hurip. Ketua berperan tunggal dalam kelompok dan kegiatan kelompok hanya sebatas pembagian bibit. Pada periode kepemimpinan kedua sudah terbentuk kepengurusan baru dengan adanya seorang sekretaris dan seorang bendahara, namun kelompok belum menetapkan tugas dari masing-masing pengurus, peraturan peraturan dan kegiatan-kegiatan kelompok. Berdasarkan kelas kemampuannya, kelompok tani Hurip termasuk ke dalam kelompok tani tingkat lajut dan sudah terdaftar di Dinas Pertanian Kabupaten Bogor. Kelompok tani Hurip sering mendapat bantuan dari pemerintah melalui Unit Pelaksana Teknis Dinas (UPTD) Kecamatan Darmaga. Adapun jenis bantuan tersebut antara lain berupa pupuk (NPK,Urea), bibit padi, bibit kacang. Sejak tahun 2006 kelompok tani Hurip mendapat bantuan aset dari Dinas Pertanian, Kabupaten Bogor berupa traktor. Pengelolaan aset ini diserahkan kepada kelompok tani dengan harapan manfaatnya dapat dirasakan oleh seluruh anggota kelompok tani Hurip. Dengan demikian dibutuhkan adanya pendampingan dari berbagai pihak.

Pendampingan pada kelompok tani Hurip dilakukan oleh mahasiswa IPB sejak Februari sampai Juni 2007, yang dihadiri oleh lebih dari 25 anggota. Pada pertemuan ini dilakukan sosialisasi kepada para anggota kelompok, bahwa tujuan kedatangan mahasiswa adalah untuk menyatakan ketersediaan mahasiswa membantu kelompok. Pada pertemuan ketiga yang dilaksanakan pada tanggal 2 Maret 2007, kelompok mulai membahas pentingnya peraturan dalam kelompok. Pertemuan tidak hanya secara formal saja, namun pengurus dan mahasiswa sering berdiskusi di luar forum untuk membicarakan mengenai kelembagaan dan permasalahan-permasalahan yang ada di kelompok tani Hurip. Permasalahan tesebut antara lain mengenai struktur organisasi, tugas pengurus dan peraturan kelompok dalam kehadiran pertemuanpertemuan selanjutnya. Pada tanggal 23 Maret 2007 dengan dihadiri oleh 21 anggota, kelompok tani Hurip menetapkan visi dan misi, struktur organisasi, tugas 
pengurus dan peraturan kelompok. Kelompok selalu melakukan pendataan ulang dari setiap tahunnya.

\section{Hubungan Antara Karakteristik Responden dan Aspek-aspek Penyuluh Terhadap Pendapatan Usahatani Petani Ubi jalar}

Faktor-faktor yang berpengaruh nyata terhadap pendapatan usahatani di kelompok tani Hurip adalah umur, tingkat pendidikan, pengalaman usahatani, frekuensi kunjungan penyuluh, kesesuaian materi, pelayanan informasi dan partisipasi penyuluhan sedangkan faktor-faktor yang tidak berpengaruh nyata adalah, status anggota. Hasil pendugaan model analisis regresi linier berganda menunjukan bahwa nilai koefisien determinasi $\left(\mathrm{R}^{2}\right)$ sebesar 78,9 persen dengan nilai determinasi terkorelasi $\left(\mathrm{R}^{\text {square }}\right)$ sebesar 77,0 persen dari variasi yang mempengaruhi pendapatan dapat dijelaskan secara bersama-sama oleh model. Faktor-faktor tersebut diduga berpengaruh terhadap pendapatan petani ubi jalar. Ini berarti pendapatan petani dapat dipengaruhi oleh variabel umur petani, tingkat pendidikan, pengalaman bertani, status anggota. Sisanya 21,1 persen yaitu diterangkan oleh variabel lain yang tidak dimasukan ke dalam model, antara lain seperti jumlah tanggungan keluarga, luas lahan dll.

Dengan analisis regresi linear berganda dapat dilakukan uji $F$ untuk menguji variabel bebas yang digunakan dalam melihat hubungan karakteristik petani dan aspek penyuluhan terhadap pendapatan usahatani. Nilai F-hitung pada model penduga yaitu 11,878 , nilai tersebut lebih besar dari nilai F-tabel yaitu 2,47. Pada kondisi tersebut menjelaskan bahwa secara keseluruhan faktor hubungan karakteristik responden yang digunakan secara bersama-sama memiliki pengaruh nyata terhadap pendapatan petani ubi jalar pada selang kepercayaan 95 persen. Nilai uji t yang diperoleh menunjukan variabel umur dan tingkat pendidikan signifikan pada taraf nyata 0,2 dan variabel pengalaman bertani signifikan pada taraf nyata 0,05 .

Model penduga analisis regresi linear berganda yang telah disusun selanjutnya dianalisis untuk menunjukan tingkat kelayakan berdasarkan asumsi OLS. Asumsi tersebut terdiri dari multikolinearitas dan homoskedasitas. Analisis mengenai multikolinearitas dapat dilihat dari nilai VIF (Variance Inflation Factors) menunjukan bahwa angka VIF berada di sekitar angka satu dan mempunyai angka Tolerance mendekati 1 , hal ini berarti tidak terdapat gejala multikolinearitas. Melihat pengaruh masing-masing variabel yang mempengaruhi pendapatan petani Hurip, maka didapat fungsi regresi linear berganda sebagai berikut:

\section{$\mathrm{Y}=1543.311-5,280 \mathrm{X}_{1}+28.628 \mathrm{X}_{2}$ $+15,257 \mathrm{X}_{3}+30.499 \mathrm{X}_{4}$}

Hasil pendugaan koefisien dan uji signifikansi variabel menunjukan bahwa variabel umur bertanda negatif dan tidak berpengaruh nyata terhadap pendapatan petani. Nilai koefisien regresi sebesar 5,280 yang berarti bahwa setiap penambahan satu tahun umur petani akan mengakibatkan menurunnya pendapatan sebesar $\mathrm{Rp}$ 5,280 hal ini dikarenakan waktu dan hidup petani telah dicurahkan untuk menekuni kegiatan pekerjaan bertaninya, sehingga semakin tua umur petani semakin berkurang produktivitasnya yang mengakibatkan menurunnya pendapatan petani. Variabel tingkat pendidikan bertanda positif dan nyata pada $\alpha 0,2$. Semakin tinggi tingkat pendidikan seseorang, maka semakin baik pula pengetahuan, keterampilan dan sikapnya, sehingga semakin cepat dalam melakukan analisa dalam kegiatan usahatani yang menyebabkan pendapatan usahataninya meningkat. Hal ini juga berkaitan dengan cara berfikir petani tersebut dalam menyerap informasi yang diberikan oleh penyuluh, nilai koefisien regresi sebesar 28,628 berarti bahwa setiap penambahan 1 tahun pendidikan petani akan 
meningkatkan pendapatan sebesar $\mathrm{Rp}$ 28,628 Variabel pengalaman usahatani menunjukan nilai positif dan nyata pada $\alpha$ 0,05 serta signifikan terhadap peningkatan pendapatan petani. Implikasinya bahwa untuk peningkatan pendapatan membutuhkan pengalaman berusahatani yang lama. Nilai koefisien sebesar 15,257 yang berarti setiap penambahan 1 tahun pengalaman petani, dapat meningkatkan pendapatan sebesarRp 15,257. ini juga menjelaskan bahwa pengalaman dalam berusahatani merupakan investasi sumberdaya manusia yang berarti bahwa petani belajar dari waktu ke waktu. Variabel status anggota bertanda positif, akan tetapi tidak berpengaruh nyata terhadap peningkatan pendapatan petani. Variabel status anggota memiliki nilai koefisien 30,499, yang artinya jika responden menjadi anggota PUAP maka pendapatan akan lebih tinggi Rp 30,499. Hal ini membuktikan petani yang menjadi peserta program PUAP lebih menguntungkan dibandingkan petani yang tidak menjadi peserta program. hal tersebut konsisten dengan penelitian Cahya (2011).

Tabel 2. Hubungan Antara Karakteristik Responden dan Aspek Penyuluhan

\begin{tabular}{|c|c|c|c|c|c|c|c|c|}
\hline \multirow{2}{*}{\multicolumn{2}{|c|}{ Model }} & \multicolumn{2}{|c|}{$\begin{array}{l}\text { Unstandardized } \\
\text { Coefficients }\end{array}$} & \multirow{2}{*}{$\begin{array}{c}\text { Standardized } \\
\text { Coefficients } \\
\text { Beta } \\
\end{array}$} & \multirow[t]{2}{*}{$\mathbf{T}$} & \multirow[t]{2}{*}{ Sig. } & \multicolumn{2}{|c|}{$\begin{array}{c}\text { Collinearity } \\
\text { Statistics }\end{array}$} \\
\hline & & B & Std. Error & & & & Tolerance & VIF \\
\hline \multirow[t]{5}{*}{1} & (Constant) & 1543.311 & 194.460 & & 7.936 & .000 & & \\
\hline & Umur & -5.280 & 3.334 & -.258 & -1.584 & .126 & .624 & 1.602 \\
\hline & Pendidikan & 28.628 & 8.626 & .470 & 3.319 & .003 & .823 & 1.215 \\
\hline & Pengalaman & 15.257 & 3.556 & .623 & 4.290 & .000 & .782 & 1.279 \\
\hline & status.anggota & 30.499 & 67.264 & .061 & .453 & .654 & .912 & 1.097 \\
\hline
\end{tabular}

\section{Peranan Penyuluhan Terhadap Peningkatan Pendapatan Petani.}

Hasil pendugaan model analisis regresi linier berganda menunjukan bahwa nilai koefisien determinasi $\left(\mathrm{R}^{2}\right)$ sebesar 68,7 persen dengan nilai determinasi terkorelasi $\left(\mathrm{R}^{\text {square }}\right)$ sebesar 76,6 persen dari variasi yang mempengaruhi pendapatan dapat dijelaskan secara bersama-sama oleh model. Faktor-faktor tersebut berpengaruh terhadap pendapatan petani ubi jalar. Ini berarti keragaman pendapatan petani dapat dijelaskan oleh variabel kesesuaian materi penyuluhan, pelayanan informasi penyuluhan, partisipasi kegiatan penyuluhan, dan kunjungan penyuluh. Sisanya 23,4 persen dapat diterangkan oleh variabel lain yang tidak dimasukan ke dalam model. Faktorfaktor lain di luar model yang diduga berpengaruh terhadap pendapatan petani ubi jalar antara lain seperti dukungan kelompok tani, teknik penyuluhan dan lain-lain. Dengan analisis regresi linear berganda dapat dilakukan uji $\mathrm{F}$ untuk menguji variabel bebas yang digunakan dalam melihat pengaruh aspek penyuluhan terhadap pendapatan. Nilai F-hitung pada model penduga yaitu 8,900 , nilai tersebut lebih besar dari nilai F-tabel yaitu 2,76. Pada kondisi tersebut menjelaskan bahwa secara keseluruhan faktor penyuluhan yang digunakan secara bersama-sama memiliki pengaruh nyata terhadap pendapatan petani ubi jalar pada selang kepercayaan 95 persen.

$\begin{array}{rcr}\text { Nilai uji t yang } & \begin{array}{r}\text { diperoleh } \\ \text { menunjukan } \\ \text { variabel }\end{array} \\ \text { penyuluhan, } & \text { kunjungan } & \text { penyuluh }\end{array}$ signifikan pada $\alpha \quad 0,2$ dan variabel kesesuaian materi signifikan pada $\alpha 0,05$. Variabel kesesuaian materi penyuluhan, pelayanan informasi penyuluhan, partisipasi penyuluhan dan kunjungan penyuluh menunjukan nilai positif, yang artinya penambahan atau pengurangan dari variabel tersebut menyebabkan penambahan pendapatan petani. Model 
Tabel 3. Hasil Pendugaan Analisis Regresi Linear Berganda Pada Aspek Penyuluhan

\begin{tabular}{|c|c|c|c|c|c|c|c|c|}
\hline \multirow{2}{*}{\multicolumn{2}{|c|}{ Model }} & \multicolumn{2}{|c|}{$\begin{array}{l}\text { Unstandardized } \\
\text { Coefficients }\end{array}$} & \multirow{2}{*}{$\begin{array}{c}\text { Standa } \\
\text { rdized } \\
\text { Coeffic } \\
\text { ients } \\
\text { Beta }\end{array}$} & \multirow[t]{2}{*}{$\mathbf{t}$} & \multirow[t]{2}{*}{ Sig. } & \multicolumn{2}{|c|}{$\begin{array}{l}\text { Collinearity } \\
\text { Statistics }\end{array}$} \\
\hline & & B & Std. Error & & & & $\begin{array}{c}\text { Tolera } \\
\text { nce }\end{array}$ & VIF \\
\hline \multirow[t]{5}{*}{1} & (Constant) & 1035.142 & 332.096 & & 3.117 & .005 & & \\
\hline & kesesuaian.materi & 149.246 & 47.974 & .505 & 3.111 & .005 & .816 & 1.225 \\
\hline & pelayanan.informasi & 31.414 & 23.994 & .222 & 1.309 & .202 & .746 & 1.340 \\
\hline & partisipasi.penyuluhan & 92.158 & 80.966 & -.220 & 1,795 & .085 & .700 & 1.429 \\
\hline & kunjungan.penyuluhan & 20.766 & 13.178 & .248 & 1.576 & .128 & .867 & 1.153 \\
\hline
\end{tabular}

penduga analisis regresi linear berganda yang telah disusun selanjutnya dianalisis untuk menunjukan tingkat kelayakan berdasarkan asumsi OLS. Asumsi tersebut terdiri dari multikolinearitas dan homoskedasitas. Analisis mengenai multikolinearitas dapat dilihat dari nilai VIF (Variance Inflation Factors). Angka VIF berada di sekitar angka satu dan mempunyai angka Tolerance mendekati 1, hal ini berarti tidak terdapat gejala multikolinearitas. Melihat pengaruh masing-masing variabel yang mempengaruhi pendapatan petani Hurip, maka didapat fungsi regresi berganda sebagai berikut:

$Y=1035,142+149.246 X_{5}+31.414 X_{6}$ $+92.158 X_{7}+20.766 X_{8}$

Variabel kesesuaian materi penyuluhan bertanda positif dan nyata pada $\alpha 0,05$. Nilai koefisien sebesar 149.246 yang berarti kesesuaian materi yang diperoleh petani dapat meningkatkan pendapatan sebesar Rp 149.246,- dengan kecocokan materi penyuluhan dan praktik di lapang secara langsung dapat membantu petani untuk lebih mudah dalam mengadopsi materi tersebut. Variabel pelayanan informasi penyuluhan bertanda positif dan nyata pada $\alpha 0,2$, Nilai koefisien sebesar 31.414 yang berarti bahwa pendapatan petani akan meningkat sebesar $\mathrm{Rp} 31,414$ apabila pelayanan informasi diberikan secara rutin kepada petani. Variabel partisipasi kegiatan penyuluhan bertanda positif dan nyata pada $\alpha 0,2$. Nilai koefisien sebesar 92.158 yang berarti bahwa peningkatan pendapatan petani akan menigkat sebesar Rp 92.158 dengan diadakannya kegiatan penyuluhan rutin yang dihadiri oleh peserta yaitu petani. Variabel Kunjungan penyuluh bertanda positif dan nyata pada $\alpha$ 0,2 . Nilai koefisien sebesar 20,766 yang berarti dimana setiap kunjungan rutin dari penyuluh setiap bulannya sekitar 5 sampai dengan 10 kali kunjungan akan meningkatkan pendapatan petani sebesar Rp 20,766,-.

\section{KESIMPULAN DAN IMPLIKASI KEBIJAKAN \\ Kesimpulan dari penelitian ini adalah bahwa faktor-faktor yang} berpengaruh nyata terhadap pendapatan usahatani di kelompok tani Hurip adalah umur, tingkat pendidikan, pengalaman usahatani, frekuensi kunjungan penyuluh, kesesuaian materi, pelayanan informasi dan partisipasi penyuluhan. Sedangkan yang tidak berpengaruh nyata adalah faktor status anggota.

\section{DAFTAR PUSTAKA}

Badan Pusat Statistika Nasional. 2010. Berbagai tahun. Luas panen produktivitas- Produksi Tanaman Ubi Jalar Provinsi Jawa Barat Tahun 2000-2011. Jakarta: Badan pusat Pusat Statistik. www.bps.go.id. (diakses pada 20 Oktober 2013).

Badan Pusat Statistika Nasional. 2011 Berbagai tahun. Luas panen 
produktivitas- Produksi Tanaman Ubi Jalar Provinsi Jawa Barat Tahun 2000-2011. Jakarta: Badan pusat Pusat Statistik. www.bps.go.id. (diakses pada 15 Desember 2013).

Badan Pusat Statistika Nasional. 2012. Berbagai tahun. Luas panen produktivitas- Produksi Tanaman Ubi Jalar Provinsi Jawa Barat Tahun 2000-2011. Jakarta: Badan pusat Pusat Statistik.(diakses pada 15 Oktober 2013).

Badan Pusat Statistika Kabupaten Bogor. 2009. Kabupaten Bogor Dalam angka. Bogor : BPS Kabupaten Bogor. www.bps.go.id. (diakses pada10 September 2013)

Badan Pusat Statistika Nasional. 2013. Berbagai tahun. Badan Pusat Statistika Kabupaten Bogor. 2013. Kabupaten Bogor Dalam angka. Bogor : BPS Kabupaten Bogor. www.bps.go.id. (diakses pada10 September 2013).

Cahya Majmudinrohman. 2011. Pengaruh Kemitraan Terhadap Pendapatan Usahatani Tebu di Kecamatan Trangkil Pati Jawa Tengah [skripsi]. Fakultas Pertanian. IPB. Bogor. www.ipb.ac.id (Diakses Maret,2014).
Departemen Pertanian. 2010. Rencana Pembangunan Pertanian. Departemen pertanian Jakarta. www.deptan.go.id . (diakses pada11 Oktober 2013).

Direktorat Jendral Tanaman Pangan Kementrian Pertanian. 2011. Rencana Strategis Direktorat Jendral Tanaman Pangan 2010-1014. www.deptan.go.id (diakses pada 11 oktober 2013).

Departemen Pertanian. 2009. Rencana Pembangunan Pertanian. Departemen Pertanian. Jakarta. www.deptan.go.id. (diakses pada 11 Oktober 2013).

Mardikanto T. 2001. Prosedur Penelitian Penyuluhan Pembangunan. Jakarta.

Mubyarto. 1989. Pengantar Ekonomi Pertanian. Jakarta. LP3ES

Suhardiyono L. 1990. Penyuluhan : Petunjuk bagi Penyuluhan Pertanian Penerbit Erlangga. Jakarta .

Soekartawi. 1986. Ilmu Usahatani dan Penelitian Untuk Pengembangan petani Kecil. UI. Jakarta. 2010.

Sugiyono Metode Penelitian Bisnis. Alfabeta. Bandung 